\title{
STUDY OF SERUM CALCIUM, MAGNESIUM, URIC ACID AND LIVER ENZYMES IN PREGNANCY INDUCED HYPERTENSION
}

\author{
Tammu Anusha1, Thumma Sankaranarayana² \\ ${ }^{1}$ Consultant Biochemist and Quality Manager, Department of Biochemistry, Shree Krishna Diagnostics, Kukatpally, Hyderabad, \\ Telangana. \\ ${ }^{2}$ Assistant Professor, Department of Biochemistry, Government Siddhartha Medical College, Gunadala, Vijayawada, A. P.
}

\section{ABSTRACT}

\section{BACKGROUND}

The lowering of serum calcium can cause an elevation of blood pressure in pre-eclamptic mothers. Magnesium is a potent vasodilator of uterine and mesenteric arteries and aorta. Magnesium also increases NO production causing vasodilation. Elevation of uric acid in preeclampsia is due to factors such as abnormal renal clearance, increased tissue breakdown, acidosis and a rise in the activity of the xanthine oxidase/ dehydrogenase enzyme. In preeclampsia hypervascularisation and vasoconstriction of liver leads to liver cell injury and alteration of cell membrane permeability and damage to the cells which allows intracellular enzymes to leak into the blood leading to elevated liver enzymes like AST, ALT and Alkaline phosphatase.

Aims and Objectives of the Study- To estimate and compare the levels of serum calcium, magnesium, uric acid and liver enzymes in women with preeclampsia and normal pregnant women.

\section{MATERIALS AND METHODS}

This case control study was conducted at GGH, Vijayawada, Andhra Pradesh. Data was collected from 50 preeclampsia cases and 50 normal healthy pregnancies in the Department of Obstetrics and Gynaecology.

\section{RESULTS}

Mean Gestational age showed high significance with mean \pm SD of cases at $36.38 \pm 4.19$ weeks compared to that of controls at $39.62 \pm 1.16$ weeks with a 'p' value of $<0.001$. Systolic BP $(150.4 \pm 19.37 \mathrm{mmHg}$ vs. $109.6 \pm 7.55 \mathrm{mmHg})$ and mean \pm SD of Diastolic BP (100.6 $\pm 14.05 \mathrm{mmHg}$ vs. $75.4 \pm 5.30 \mathrm{mmHg})$ of the pre-eclamptic group are significantly higher than the control group. Value of calcium in pre-eclamptic women was significantly low $(8.57 \pm 0.96 \mathrm{mg} / \mathrm{dL}$ vs. $9.88 \pm 1.38 \mathrm{mg} / \mathrm{dL} ; \mathrm{p}<0.001)$. Magnesium in preeclamptic women was lower than normal pregnant women $(1.92 \pm 0.36 \mathrm{mg} / \mathrm{dL}$ vs. $2.26 \pm 0.25 \mathrm{mg} / \mathrm{dL} ; \mathrm{p}<0.001)$. The serum uric acid in pre-eclamptic women was significantly more than normal pregnant women $(6.66 \pm 2.21 \mathrm{mg} / \mathrm{dL} \mathrm{vs.} 4.51 \pm 1.18 \mathrm{mg} / \mathrm{dL}$, $\mathrm{p}<0.001)$. ALP, AST and ALT were increased in cases compared to controls and are statistically highly significant ( $<<0.001)$.

\section{CONCLUSION}

Based on the present study, serum calcium and magnesium levels are low in pre-eclamptic mothers. Pregnant women should be educated about nutrition during pregnancy and probable risks of inappropriate diet should be informed. Thus, it can be concluded that Calcium and Magnesium can be evaluated at an early date, so that such mineral deficiencies can be treated by appropriate Calcium and Magnesium supplements. Uric acid and Liver enzymes can possibly be used as biomarkers for identifying and avoiding adverse pregnancy outcomes by prompt intervention.

\section{KEYWORDS}

ALT: Alanine Transaminase, AST: Aspartate Transaminase, ALP: Alkaline Phosphatase.

HOW TO CITE THIS ARTICLE: Anusha T, Sankaranarayana T. Study of serum calcium, magnesium, uric acid and liver enzymes in pregnancy induced hypertension. J. Evolution Med. Dent. Sci. 2018;7(11):1347-1352, DOI: 10.14260/jemds/2018/306

\section{BACKGROUND}

The term "PIH" is restricted to hypertension in pregnant women who have no pre-existing overt chronic hypertension or renal diseases, and no high blood pressure or proteinuria before 20 weeks' gestation and in whom hypertension and proteinuria occur for the first time during the second half of pregnancy (after 20 weeks), during labour or during the puerperium and subside after delivery. "PIH" herein includes gestational hypertension (Hypertension without Proteinuria),

'Financial or Other Competing Interest': None.

Submission 23-01-2018, Peer Review 25-02-2018,

Acceptance 03-03-2018, Published 12-03-2018.

Corresponding Author:

Dr. Thumma Sankaranarayana,

F. No. 401, Bhuvaneswari Heights,

Sri Ramachandra Nagar,

Behind Aayush Hospital,

Vinayaka Temple Road, Vijayawada-520008.

E-mail: drsankartumma@yahoo.co.in

DOI: $10.14260 /$ jemds $/ 2018 / 306$

\section{(c) $(1) \$$}

preeclampsia (Hypertension plus Proteinuria) and eclampsia (Preeclampsia plus convulsion).(1)

Calcium, Magnesium, Uric Acid Metabolism in Pregnancy and Preeclampsia: The lowering of serum calcium and the increase of intracellular calcium can cause an elevation of blood pressure in preeclamptic mothers. Magnesium is a potent vasodilator of uterine and mesenteric arteries and aorta. Magnesium also increases NO production causing vasodilation.(2) Elevation of uric acid in preeclampsia due to factors such as abnormal renal clearance, increased tissue breakdown, acidosis and a rise in the activity of the xanthine oxidase/ dehydrogenase enzyme.(3) Liver enzymes in pregnancy and preeclampsia: In preeclampsia hypervascularisation and vasoconstriction of liver leads to liver cell injury and alteration of cell membrane permeability and damage to the cells which allows intracellular enzymes to leak into the blood leading to elevated liver enzymes like AST, ALT and Alkaline phosphatase.(4)

The aim and objectives of the study is to determine the clinical value of serum calcium, magnesium, uric acid and 
liver enzymes in preeclampsia. To estimate and compare the levels of serum calcium, magnesium, uric acid and liver enzymes in women with preeclampsia and normal pregnant women. To find if there is any relationship between serum calcium, magnesium, uric acid and liver enzymes in the study group.

\section{MATERIALS AND METHODS}

This case-control study was conducted at Siddhartha Government General Hospital, Vijayawada, Andhra Pradesh. Data was collected from 50 preeclampsia cases and 50 normal healthy pregnant mothers in the Dept. of Obstetrics and Gynaecology. We have selected 50 cases and 50 controls according to our convenience.

\section{Type of Study}

Case control study.

Cases are pregnant women with preeclampsia and controls are normal healthy pregnant women.

\section{Selection (Inclusion) Criteria \\ Study (Case) Group-}

- Pregnant females with a singleton pregnancy.

- $\quad$ Age range between 18 and 35 years.

- Gestational age: All women in the $3^{\text {rd }}$ trimester, the gestational period ranged from 30 - 42 weeks. Calculated from the first day of the last menstrual period.

- No history of previous urinary tract troubles and no evidence of UTI.

- $\quad$ Not diabetic.

The cases were selected on the basis of simple random sampling method. The study protocol was approved by the Institutional Ethical Committee and informed consent was obtained from the subjects under study.

\section{Control Group}

The control group were women who fulfil the same previously mentioned criteria, but who did not develop hypertension during the $3^{\text {rd }}$ trimester. They were all normotensive with a systolic blood pressure of $130 \mathrm{mmHg}$ or less and a diastolic blood pressure of $80 \mathrm{mmHg}$ or less.

\section{Exclusion Criteria}

In both cases and control groups, the exclusion criteria included pregnant females with disorders such as chronic renal disease, chronic hypertension, heart disease, gestational diabetes, molar pregnancy, intrauterine foetal death, urinary tract infection and twin pregnancy.

\section{Laboratory Methods}

The blood pressure was measured by the sphygmomanometer, while the patient was lying on a couch on her side. The reading should be $140 / 90 \mathrm{mmHg}$ and above-

- The serum calcium, magnesium, uric acid and liver enzymes estimated using Robonik semi-automated analyser.

- Measurement of calcium in serum was done using Ortho Cresolphthale in complexone method (OCPC method).

- Measurement of magnesium was done using Xylidyl Blue Method.
- Measurement of uric acid was done using Modified Trinder Method.

- Measurement of ALP, AST and ALT was done using enzymatic method.

\section{Statistical Methods}

All findings were tabulated and statistically analysed using paired t-test using SPSS version 16.0. Mean and SD were calculated for age, gestational age, parity, birth weight and all the biochemical parameters. Significant level was set as $\mathrm{p}<0.05$.

Numerical variables were presented as Mean \pm Standard Deviation (Mean \pm SD), while categorical variables were presented as percentages. Continuous variables were compared using Student's ' $\mathrm{t}$ ' test. Student's ' $\mathrm{t}$ ' test with unequal variance was used to compare means between two groups at $5 \%$ level of significance. Correlation analysis was done by using Pearson correlation analysis.

\section{RESULTS}

The present study includes 50 cases with pregnancy induced hypertension and 50 controls with normal healthy pregnancy.

\section{Age Distribution in Study Population}

Mean \pm SD of age showed no significant difference with Mean \pm SD of cases at $22.62 \pm 3.61$ yrs. compared to that of controls at $23 \pm 4.04 \mathrm{yrs}$. and a p-value of 0.62 .

\section{Gestational Age in Study Population}

Mean gestational age showed high significance with Mean \pm SD of cases at $36.38 \pm 4.19$ weeks compared to that of controls at $39.62 \pm 1.16$ weeks with a p value of $<0.001$.

\section{Mean \pm SD values of Blood Pressure in Study Population}

Mean \pm SD of Systolic BP $(150.4 \pm 19.37 \mathrm{mmHg}$ vs. $109.6 \pm$ $7.55 \mathrm{mmHg}$ ) and Mean \pm SD of Diastolic BP (100.6 \pm 14.05 $\mathrm{mmHg}$ vs. $75.4 \pm 5.30 \mathrm{mmHg}$ ) of the pre-eclamptic group are significantly higher than the control group with a p-value of $<0.001$.

The Mean \pm Standard deviation value of Calcium in preeclamptic women was significantly less than normal pregnant women $(8.57 \pm 0.96 \mathrm{mg} / \mathrm{dL}$ vs. $9.88 \pm 1.38 \mathrm{mg} / \mathrm{dL} ; \mathrm{p}<0.001)$ and statistically highly significant. The Mean \pm Standard deviation values of Magnesium in pre-eclamptic women was significantly less than normal pregnant women $(1.92 \pm 0.36$ $\mathrm{mg} / \mathrm{dL}$ vs. $2.26 \pm 0.25 \mathrm{mg} / \mathrm{dL} ; \mathrm{p}<0.001$ ) and statistically highly significant. The serum uric acid in pre-eclamptic women was significantly more than normal pregnant women $(6.66 \pm 2.21 \mathrm{mg} / \mathrm{dL}$ vs. $4.51 \pm 1.18 \mathrm{mg} / \mathrm{dL}, \mathrm{p}<0.001)$. The Mean \pm SD of Alkaline phosphatase, AST and ALT were increased in cases compared to controls and are statistically highly significant $(\mathrm{p}<0.001)$.

Calcium and Magnesium have shown a significant negative correlation with Systolic Blood pressure, whereas uric acid and liver enzymes have shown a significant positive correlation with systolic blood pressure. 


\begin{tabular}{|c|c|c|c|c|c|}
\hline $\begin{array}{c}\text { Study Group } \\
(\mathbf{n = 1 0 0 )}\end{array}$ & $\begin{array}{c}\text { PIH Cases } \\
(\mathbf{n = 5 0 )}\end{array}$ & $\begin{array}{c}\text { Controls } \\
(\mathbf{n = 5 0 )}\end{array}$ & T-Statistic & P-Value & Inference \\
\hline $\begin{array}{c}\text { Gestational age at } \\
\text { admission for } \\
\text { delivery }\end{array}$ & $36.38 \pm 4.19$ & $39.62 \pm 1.16$ & 5.26 & HS \\
\hline \multicolumn{7}{|r}{} \\
\hline \multicolumn{7}{|c|}{ Table 1. Mean \pm SD Values of Gestational Age in Study Population } \\
\hline
\end{tabular}

\begin{tabular}{|c|c|c|c|c|c|}
\hline $\begin{array}{c}\text { Study Group } \\
(\mathbf{n = 1 0 0 )}\end{array}$ & $\begin{array}{c}\text { PIH Cases } \\
(\mathbf{n = 5 0 )}\end{array}$ & $\begin{array}{c}\text { Controls } \\
(\mathbf{n = 5 0 )}\end{array}$ & T-Statistic & P-Value & Inference \\
\hline $\begin{array}{c}\text { Systolic Blood } \\
\text { Pressure } \\
\text { (in mmHg) }\end{array}$ & $150.4 \pm 19.37$ & $109.6 \pm 7.55$ & 13.87 & HS \\
\hline $\begin{array}{c}\text { Diastolic Blood } \\
\text { Pressure } \\
\text { (in mmHg) }\end{array}$ & $100.6 \pm 14.05$ & $75.4 \pm 5.30$ & 11.86 & $<0.001$ & HS \\
\hline \multicolumn{2}{|c|}{ Table 2. Mean \pm SD Values of Blood Pressure in Study Population } \\
\hline
\end{tabular}

\begin{tabular}{|c|c|c|c|c|c|}
\hline $\begin{array}{c}\text { Biochemical } \\
\text { Parameter }\end{array}$ & PIH Cases & Controls & T-Statistic & P-Value & Inference \\
\hline Calcium (mg/dL) & $8.57 \pm 0.96$ & $9.88 \pm 1.38$ & 5.4 & $<0.001$ & HS \\
\hline $\begin{array}{c}\text { Magnesium } \\
\text { (mg/dL) }\end{array}$ & $1.92 \pm 0.36$ & $2.26 \pm 0.25$ & 5.5 & $<0.001$ & HS \\
\hline \multicolumn{7}{|r}{} \\
\hline
\end{tabular}

\begin{tabular}{|c|c|c|c|c|c|}
\hline $\begin{array}{c}\text { Biochemical } \\
\text { Parameter }\end{array}$ & PIH Cases & Controls & T-Statistic & P-Value & Inference \\
\hline Uric Acid (mg/dL) & $6.66 \pm 2.21$ & $4.51 \pm 1.18$ & 6.0 & $<0.001$ & HS \\
\hline \multicolumn{7}{|r|}{ Table 4. Mean \pm SD Values of Uric Acid in Study Population } \\
\hline
\end{tabular}

\begin{tabular}{|c|c|c|c|c|c|}
\hline Biochemical Parameter (IU/L) & PIH Cases & Controls & T-Statistic & P-Value & Inference \\
\hline ALP & $180.5 \pm 49.24$ & $95.6 \pm 49.22$ & 8.6 & $<0.001$ & HS \\
\hline SGOT/ AST & $54.7 \pm 32.69$ & $25.08 \pm 7.25$ & 6.2 & $<0.001$ & HS \\
\hline SGPT/ ALT & $36.7 \pm 28.77$ & $18.56 \pm 10.42$ & 4.1 & $<0.001$ & HS \\
\hline
\end{tabular}

\begin{tabular}{|c|c|c|}
\hline Biochemical Parameter & Pearson Correlation Coefficient (R Value) & Statistical Inference \\
\hline Calcium & -0.36 & $\mathrm{p}=0.01$ \\
\hline Magnesium & -0.50 & $\mathrm{p}<0.001$ \\
\hline Uric Acid & 0.50 & $\mathrm{p}<0.001$ \\
\hline Alkaline Phosphatase & 0.64 & $\mathrm{p}<0.001$ \\
\hline SGOT & 0.58 & $\mathrm{p}<0.001$ \\
\hline SGPT Table 6. Pearson Correlation between Systolic Blood Pressure and Biochemical \\
Parameters of Pregnancy Induced Hypertension
\end{tabular}

\begin{tabular}{|c|c|c|}
\hline Biochemical Parameter & Pearson Correlation Coefficient (R Value) & Statistical Inference \\
\hline Calcium & -0.21 & $\mathrm{p}=0.14$ \\
\hline Magnesium & -0.40 & $\mathrm{p}=0.004$ \\
\hline Uric Acid & 0.39 & $\mathrm{p}=0.005$ \\
\hline Alkaline Phosphatase & 0.64 & $\mathrm{p}<0.001$ \\
\hline SGOT & 0.51 & $\mathrm{p}<0.001$ \\
\hline SGPT Table 7. Pearson Correlation between Diastolic Blood Pressure and Biochemical \\
Parameters of Pregnancy Induced Hypertension \\
\hline
\end{tabular}

\begin{tabular}{|c|c|c|c|}
\hline Age (in Yrs.) & PIH Cases n= 50 (\%) & Controls n= 50 (\%) & Total n= 100 (\%) \\
\hline $15-19$ & $8(16 \%)$ & $4(11 \%)$ & 12 \\
\hline $20-24$ & $28(58 \%)$ & $33(64 \%)$ & 61 \\
\hline $25-29$ & $11(21 \%)$ & $9(18 \%)$ & 20 \\
\hline $30-35$ & $3(5 \%)$ & $4(7 \%)$ & 7 \\
\hline Total & $\mathbf{5 0}(\mathbf{1 0 0} \%)$ & $\mathbf{5 0}(100 \%)$ & $\mathbf{1 0 0}(100 \%)$ \\
\hline
\end{tabular}

The Chi-square statistic is 2.086. The p-value is 0.55 . The result is not significant at $\mathrm{p}<0.05$. Degrees of freedom $=3$. 


\begin{tabular}{|c|c|c|c|}
\hline Parity & Cases n= 50 (\%) & Controls n= 50 (\%) & Total n= 100 (\%) \\
\hline Primi $\left(\mathrm{P}_{0+0}\right)$ & $25(52 \%)$ & $20(43 \%)$ & $45(49 \%)$ \\
\hline Second $\left(\mathrm{P}_{1+0}\right)$ & $11(21 \%)$ & $24(46 \%)$ & $35(27 \%)$ \\
\hline Third $\left(\mathrm{P}_{2+0}\right)$ & $9(17 \%)$ & $3(5 \%)$ & $72(14 \%)$ \\
\hline Fourth $\left(\mathrm{P}_{3+0}\right)$ & $4(8 \%)$ & $3(6 \%)$ & $1(8 \%)$ \\
\hline Fifth $\left(\mathrm{P}_{4+0}\right)$ & $1(2 \%)$ & $0(0 \%)$ & $\mathbf{1 0 0}(\mathbf{1 0 0 \% )}$ \\
\hline Total & $\mathbf{5 0}(\mathbf{1 0 0} \%)$ & $\mathbf{5 0}(\mathbf{1 0 0} \%)$ & \\
\hline \multicolumn{2}{|c|}{} \\
\hline
\end{tabular}

The Chi-square statistic is 9.527. The $\mathrm{p}$-value is 0.04 . The result is significant at $\mathrm{p}<0.05$. Degrees of freedom $=4$.

\begin{tabular}{|c|c|c|c|}
\hline Gestational Age (In Weeks) & PIH Cases n= 50 (\%) & Controls n= 50 (\%) & Total n= 100 (\%) \\
\hline $24-27$ & $1(3 \%)$ & $0(0 \%)$ & $1(2 \%)$ \\
\hline $28-31$ & $6(12 \%)$ & $0(0 \%)$ & $6(9 \%)$ \\
\hline $32-35$ & $9(18 \%)$ & $0(0 \%)$ & $9(14 \%)$ \\
\hline $36-40$ & $34(67 \%)$ & $50(100 \%)$ & $84(75 \%)$ \\
\hline Total & $\mathbf{5 0}(100 \%)$ & $\mathbf{5 0}(100 \%)$ & $\mathbf{1 0 0}(100 \%)$ \\
\hline \multicolumn{2}{|c|}{ Table 10. Chi-Square Test for Gestational Age at Delivery } \\
\hline
\end{tabular}

The Chi-square statistic is 19.0476 . The $p$-value is 0.0002 . The result is significant at $p<0.05$. Degrees of freedom $=3$.

\section{DISCUSSION}

The Mean \pm SD of ages of the preeclamptic women and the normal healthy women are not significantly different, which correlates with the study of Golmohammad Lou et al,(5) Tavana $\mathrm{Z}$ et al(6) and Sangeeta N(7) et al also did not show any significance in age, indicating that both the groups are of comparable age.

The Mean \pm SD of gestational ages of the preeclamptic women and the normal healthy women are significantly different as is shown in Table 1 . The present study showed a Mean \pm SD of $36.38 \pm 4.19$ weeks in cases and $39.62 \pm 1.16$ weeks in controls with a highly significant p-value of $<0.001$, which correlates with the study of Deepa V Kanagal et al(8) and of Harma et al,(9) Farah Saleh et al(10) and Chaurasia et al.(11) Mean \pm SD of systolic BP $(153 \pm 19.39 \mathrm{mmHg}$ vs. $109.6 \pm 7.55 \mathrm{mmHg}$ ) and Mean \pm SD of Diastolic BP $(102.4 \pm 13.99 \mathrm{mmHg}$ vs. $75.4 \pm 5.30 \mathrm{mmHg})$ of the preeclamptic group are significantly higher than the control group ( $\mathrm{p}<0.001$ ) as shown in Table 2 , which correlates well with the study of Rubina Aziz et al(12) and also with the study of Deepa V Kanagal et al(8) and Farah Saleh et al.(10)

\section{Calcium Levels in Hypertensive Disorders of Pregnancy}

The present study has shown that maternal total serum calcium levels are significantly lower in pregnancy induced hypertension than in normal pregnant women as shown in Table 3 with Mean \pm SD of $8.57 \pm 0.96 \mathrm{mg} / \mathrm{dL}$ in preeclamptic pregnant women and a Mean \pm SD of $9.88 \pm 1.38 \mathrm{mg} / \mathrm{dL}$ in controls with a highly significant $p$-value of $<0.001$. These results are in accordance with the findings of Naser et al and Sendhav Sandip et al.(13)

\footnotetext{
Magnesium Levels in Hypertensive Disorders of Pregnancy

The present study has shown that maternal total serum magnesium levels can be significantly lower in pregnancyinduced hypertension than in normal pregnant women as shown in Table 3 with Mean \pm SD of $1.93 \pm 0.34 \mathrm{mg} / \mathrm{dL}$ in pregnant women and a Mean \pm SD of $2.26 \pm 0.25 \mathrm{mg} / \mathrm{dL}$ in controls with $\mathrm{p}$-value of $<0.001$. This study was similar to the findings of previous studies by C Punthumapol et al,(14) Sendhav Sandip et al,(13) Zohreh Tavana et al and
}

Handwerker SM et al,(15) Khan AMC and Sullivan et al.(16)

Uric Acid Levels in Hypertensive Disorders of Pregnancy The present study Mean \pm SD (Cases- $6.66 \pm 2.21 \mathrm{mg} / \mathrm{dL} /$ Controls- $4.51 \pm 1.18 \mathrm{mg} / \mathrm{dL}$ ) showed that mean uric acid levels are significantly higher in hypertensive patients when compared with controls as shown in Table 4. This finding is in accordance with the study done by Punthumapol C et al,(14) Sendhav Sandip et al,(13) Sangeeta $N$ et al(7) and Cunningham F et al. But Thangaratinam et al concluded from a meta-analysis that uric acid level measurement in pregnant women is not a strong predictive factor.(17)

\section{Liver Function Tests in Hypertensive Disorders of Pregnancy}

In the present study, the mean serum levels of ALP were significantly higher in cases $(180.5 \pm 49.24 \mathrm{IU} / \mathrm{L})$ when compared with controls $(95.6 \pm 49.22 \mathrm{IU} / \mathrm{L})$ with a p-value of $<0.001$ as shown in Table 5. These findings correlate with the study of Amit D Sonagra et al,(18) Dipti Mohapatra et al(19) and $S$ Paneri et al.(20) The levels of AST was significantly higher in women with preeclampsia as compared to normal pregnant women as shown in Table 5 with a Mean \pm SD of $54.7 \pm 32.69$ $\mathrm{IU} / \mathrm{L}$ in cases and $25.08 \pm 7.25 \mathrm{IU} / \mathrm{L}$ in controls with a p-value of $<0.001$. AST levels correlate with other studies by Rubina Aziz et al,(12) Dipti Mohapatra et al(19) and Paneri et al.(20)

The present study showed a significant increase in the value of ALT with a Mean \pm SD of $36.7 \pm 28.77 \mathrm{IU} / \mathrm{L}$ in cases and $18.56 \pm 10.42 \mathrm{IU} / \mathrm{L}$ in controls with a p-value of $<0.001$ as shown in Table 5. This correlates with the study of Paneri et al(20) and Dipti Mohapatra et al.(19) Thus, estimation of serum ALP, AST, ALT and Uric acid at regular interval may give insight to ongoing disease progression and organ damage. They may prove to be a useful tool to predict the maternal and foetal complications even at an earlier stage of the disease.

In the present study, Mean \pm SD of birth weight in cases was $2.49 \pm 0.76$ and that of controls was $2.75 \pm 0.58$ with a pvalue of 0.06 which is not significant, which is in contrast to the study of Deepa V Kanagal et al(8) of Naser 0 Malas et al, wherein their studies showed significantly lower birth weight in preeclamptic mothers. 


\section{Summary}

50 preeclampsia cases and 50 normal healthy pregnant women are studied. The levels of serum calcium, magnesium, uric acid and liver enzymes- ALP, AST/ ALT are analysed in both the groups-

- Maternal total serum calcium and magnesium levels are significantly lower in pregnancy-induced hypertension than in normal pregnant women and considered to be a cause of pathogenesis of PIH. Pearson's correlation analysis showed a significant negative correlation of Magnesium with systolic and diastolic blood pressure in cases. There is a significant negative correlation of Calcium with systolic blood pressure, but not with diastolic blood pressure. Mean serum uric acid levels are significantly higher in pregnancy-induced hypertensive patients when compared with controls. Maternal hyperuricaemia is found to be a strong predictor of maternal disease progression and foetal outcome.

- $\quad$ Liver enzymes ALP, AST and ALT in the present study are significantly higher in women with preeclampsia as compared to normal pregnant women. Pearson's correlation analysis showed a significant positive correlation of Uric acid, Alkaline phosphatase (ALP), Alanine transaminase (ALT) and Aspartate transaminase (AST) with systolic and diastolic blood pressure in cases.

- Thus, estimation of serum ALP, AST, ALT and Uric acid at regular interval may give insight to ongoing disease progression and organ damage. They may prove to be a useful tool to predict the maternal and foetal complications even at an earlier stage of the disease.

\section{CONCLUSION}

- Based on the present study, as serum calcium and magnesium levels are low in preeclamptic mothers and considering the high prevalence of preeclampsia, nutritional conditions of pregnant women seems to be of prime importance. Pregnant women should be educated about nutrition during pregnancy and probable risks of inappropriate diet should be informed.

- $\quad$ Possibly, serial measurements of the serum uric acid and liver enzymes from early pregnancy can bring forward a selected group of high risk women for treatment. Thus, it can be concluded that Calcium and Magnesium can be evaluated at an early date so that such mineral deficiencies can be treated by appropriate Calcium and Magnesium supplements. Uric acid and Liver enzymes can possibly be used as biomarkers for identifying and avoiding adverse pregnancy outcomes by prompt intervention.

\section{REFERENCES}

[1] Zhang J, Zeisler J, Hatch MC, et al. Epidemiology of pregnancy-induced hypertension. Epidemiologic Reviews 1997;19(2):218-32.

[2] Euser AG, Cipolla MJ. Magnesium sulfate treatment for the prevention of eclampsia: a brief review. Stroke 2009;40(4):1169-75.
[3] Bainbridge SA, Roberts JM. Uric acid as a pathogenic factor in preeclampsia. Placenta 2008;29(Suppl A):S67-72.

[4] Magnussen EB, Vatten LJ. Pregnancy cardiovascular risk factor as predictor of preeclampsia. Journal of Medicine 2007;1(4):335-9.

[5] Golmohammad LS, Amirabi A, Yazdian M, et al. Evaluation of Serum Calcium, Magnesium, Copper and Zinc levels in Women with Pre-eclampsia. Iran J Med Sci 2008;33(4):231-4.

[6] Tavana Z, Hosseinmirzaei S. Comparison on maternal serum magnesium level in pre-eclampsia and normal pregnant women. Iran Red Cres Med J 2013;15(12):e10394.

[7] Sangeeta N, Shaini L, Basar G, et al. Serum Uric Acid and homocysteine as predictors of pre-eclampsia. J Diabetes Metab 2013;4(4):259.

[8] Kanagal DV, Rajesh A, Rao K, et al. Levels of serum Calcium and Magnesium in pre-eclamptic and normal pregnancy: a study from coastal India. Journal of Clinical and Diagnostic Research 2014;8(7):0C01OC04.

[9] Harma M, Harma M, Kocyigit A. Correlation between maternal plasma homocysteine and Zinc levels in preeclamptic women. Biol Trace Elem Res 2005;104(2):97-105.

[10] Saleh F, Shukar-ud-Din S, Soomro N. Serum uric acid as predictor model for pre-eclampsia. Pak J Surg 2010;26(3):246-51.

[11] Chaurasia PP, Jadav PA, Jasani JH. Changes in serum Calcium and serum Magnesium level in pre-eclamptic vs normal pregnancy. IJBAR 2012;3(6):511-3.

[12] Aziz R, Mahboob T. Relation between preeclampsia and cardiac enzymes. ARYA Atherosclerosis Journal 2008;4(1):29-32.

[13] Sandip S, Asha K, Paulin G, et al. A Comparative study of serum uric acid, calcium and magnesium in preeclampsia and normal pregnancy. Journal of Advance Researches in Biological Sciences 2013;5(1):55-8.

[14] Punthumapol C, Kittichotpanich B. Serum calcium, magnesium and uric acid in pre-eclampsia and normal pregnancy. J Med Assoc Thai 2008;91(7):968-73.

[15] Handwerker SM, Altura BT, Altura BM. Ionised serum magnesium and potassium levels in pregnant women with pre-eclampsia and eclampsia. J Reproduc Med 1995;40(3):201-8.

[16] Khan AMC, Sullivan L, McCabe E, et al. Lack of association between serum Magnesium and the risk of hypertension and cardiovascular diseases. American Heart Journal 2010;160(4):715-20.

[17] Thangaratinam S, Ismail KM, Sharp S, et al. Accuracy of serum uric acid in predicting complications of preeclampsia: a systematic review. BJOG 2006;113(4):369-78.

[18] Sonagra AD, Dattatreya K, Murthy JDS. Serum LDH, ALP and Uric acid in hypertensive disorders of pregnancy. International Journal of Pharmacy and Biological Sciences 2012;2(3):201-9. 


\section{Jemds.com}

[19] Mohapatra D, Behera M. Relevance of variation of liver function tests in pregnancy induced hypertension. International Journal of Pharma and Bio Sciences 2013;4(1):B570-4.
Original Research Article

[20] Paneri S, Panchonia A, Varma M, et al. Evaluation of RFTs and LFTs and ascorbic acid in pre-eclampsia among women of Indore. Indian Journal of Fundamental and Applied Life Sciences 2011;1(4):312-5. http://www.cibtech.org.jls.htm. 